UDC 369.032:316.334.2:330.342.3

JEL classification: F60, L50

\author{
Войтко C. В., \\ доктор економ. наук, професор, \\ ORCID 0000-0002-2488-3210 \\ Гавриш О. А., \\ доктор техн. наук, професор, \\ ORCID 0000-0002-1961-3267
}

Згуровський О. М., канд. економ. наук ORCID 0000-0001-7539-9907

Національний технічний університет України „Київський політехнічний інститут імені Ігоря Сікорського”

\title{
ЯКІСТЬ ДЕРЖАВНОГО РЕГУЛЮВАННЯ, ЕФЕКТИВНІСТЬ РОБОТИ УРЯДУ ЧИ ПЛАН МАРШАЛЛА НА ШЛЯХУ КРАЇН ДО ІНДУСТРІЇ-4.0
}

\section{QUALITY OF PUBLIC REGULATION, EFFECTIVENESS OF GOVERNMENT OR A MARSHALL PLAN ON THE PATH OF A COUNTRY TO INDUSTRY-4.0}

\begin{abstract}
Доведено актуальність вивчення положень Індустрії-4.0 з позицій використання інформаційно-комунікаційних технологій (IKT) у виробничому процесі на існуючих сучасних підприємствах. Виявлено важливість використання положень Четвертої промислової револючії при розробиі концепцій функиіонування і розвитку економічних систем різного рівня: від підприємства до краӥни. Визначено иүілі дослідження: 1) виявлення показників, які прямо чи опосередковано визначають за класифікаційними ознаками належність країни до Індустрії-4.0; 2) аналізування результатів первинного дослідження комплексних показників Regulatory Quality ma Government Effectiveness з метою виявлення можливості керування економічною системою на державному рівні, иільовими орієнтирами якої є корегування та трансформація виробничої системи від класичної виробничої системи до Індустрії-4.0. Аналіз даних Worldwide Governance Indicators здійснено за період 2006-2016рр. Визначено лідери Індустрії-4.0 за показниками високотехнологічного експорту до загального обсягу експорту, експорту та імпорту товарів і послуг інформаційно-комунікаційних технологій. Візуалізовано співвідношення експорту та імпорту товарів інформаційно-комунікаційних технологій. Здійснено дослідження взаємного розмімення об'єктів у обраній системі координат показників Regulatory Quality ma Government Effectiveness. Проведено аналіз $i$ візуалізацію Doing Business також. Прорейтинговано крайни за результатами розрахунку відстаней та показників у системі координат Regulatory Quality ma Government Effectiveness. Зроблено висновок, щчо «план Мармалла» та подібні програми мають можливість стимулювати розвиток країн у напряму Індустрії-4.0. Науковим результатом $\epsilon$ методичний підхід до визначення можливості та підстав потрапляння країни за класифікаційними ознаками до Індустрії-4.0, який, на відміну від експертних оцінок, використовує статистичні дані та комплексні показники з метою об'єктивного оцінювання стану об'єкту та вироблення відповідних заходів для окремо взятої країни для потрапляння до когорти країн Індустрії-4.0.
\end{abstract}

Ключові слова: якість державного регулювання, ефективність роботи уряду, План Маршалла, Індустрія-4.0 
The relevance of the study of the Industry-4.0 positions from the point of view of the use of information and communication technologies (ICTs) in the production process at existing modern enterprises has been proved. The importance of using the provisions of the Fourth Industrial Revolution in the development of the concepts of the functioning and development of economic systems of different levels has been identified: from an enterprise to a country. The objectives of the study are as follows: 1) the identification of indicators that determine, directly or indirectly, the country's membership in the Industry-4.0 according to the classification criteria; 2) analysis of the results of the initial study of the complex indicators of Regulatory Quality and Government Effectiveness systems with a goal to identify the possibility of managing the economic system at a state level, the target orientation of which is the correction and transformation of the production system from the classical production system to the Industry-4.0. Worldwide Governance Indicators data analysis was performed for the period of 2006-2016. The leaders of the Industry4.0 were determined according to the indicators of high-tech exports relative to the total volume of export, export and import of goods and services of information and communication technologies. The ratio of export and import of goods of the information and communication technologies has been visualized. The research of the mutual placement of objects has been performed in the following systems - Regulatory Quality and Government Effectiveness. The Doing Business analysis and visualization has also been performed. The countries are rated as a result of calculation of distances and indicators within the Regulatory Quality and Government Effectiveness systems. It is concluded that a "Marshall Plan» and similar programs have an ability to stimulate the development of countries in the direction of Industry-4.0. The scientific result is the methodological approach that determines the possibility and grounds for the country to fall under the classification criteria to Industry-4.0, which, unlike expert assessments, it uses statistical data and integrated indicators for the objective assessment of the state of the object and the development of appropriate measures for a specific country to fall into the cohort of the countries of the Industry-4.0.

Keywords: quality of public regulation, effectiveness of government, Marshall plan, Industry-4.0.

Вступ. На сьогодні досить поширеним політичним і бізнес трендом $\epsilon$ використання положень Індустрії-4.0 (Четверта промислова революція) при розробці концепцій функціонування і розвитку економічних систем різного рівня: від підприємства до країни. Так, Індустрія-4.0 є тією парадигма, що надає можливість зважено перейти від класичної виробничої системи кінця XX-ого початку XXI-ого століття до зваженого використання інформаційнокомунікаційних технологій (IКТ) у виробничому процесі на існуючих сучасних підприємствах, а також на тих, що проектуються. Це стосується й більших об'єктів, таких як країна, регіон чи інтеграційне об'єднання країн. Аналіз саме країн за технологічним розвитком показав, що не повною мірою масштаби діяльності, виробничі можливості, інтелектуальний потенціал кожної з країн відповідає рівню країни у рейтингу високотехнологічних країн, а також у експертних заключеннях стосовно приналежності країни до Індустрії-4.0. Положення Індустрії-4.0 грунтовно досліджувалися Клаусом Швабом (Klaus Schwab) у роботі [1]. Належним чином аналіз наукових публікацій з проблематики Індустрії-4.0 здійснили Маріо Германн (Мario Hermann), Тобіас Пінтек (Tobias Pentek), Борис Отто (Boris Otto) у роботі [2]. 
Проблематикою керованості економічних систем у глобальній економіці займаються низка науковців, зокрема нобелівські лауреати Елінор Остром (Elinor Ostrom, USA) [3], Олівер Вільямсон (Oliver E. Williamson, USA) [4], Даніель Кауфманн (Daniel Kaufmann, USA). Методологію керованості окреслених нами систем розробили Аарт Край (Aart Kraay, USA), Массімо Маструзі (Massimo Mastruzzi, USA) у роботі [5].

Актуальним залишається проблематика виявлення тих важелів, які надають можливість виявити приналежність країни та іiі соціальноекономічної системи до положень Індустрії-4.0.

Постановка завдання. Визначено такі цілі дослідження: 1) виявлення показників, які прямо чи опосередковано визначають за класифікаційними ознаками належність країни до Індустрії-4.0; 2) аналізування результатів первинного дослідження комплексних показників Regulatory Quality та Government Effectiveness 3 метою виявлення можливості керування економічною системою на державному рівні, цільовими орієнтирами якої $€$ корегування та трансформація виробничої системи від класичної виробничої системи до Індустрії-4.0.

Методологія. Кореляційний аналіз для визначення залежності між показниками Regulatory Quality (якість регулювання) та Government Effectiveness (ефективність уряду). Рейтингування для формування послідовності об'єктів дослідження (у нашому випадку країн) за величиною значення показника. Порівняльний аналіз для виявлення подібності у характеристиках об'єктів.

Результати дослідження. У проекті «Світові показники управління» [5] (Worldwide Governance Indicators - WGI) використано показники 3 таких шести складових державного управління: Voice and Accountability (VA - голос і підзвітність); Political Stability and Absence of Violence/Terrorism (PSAVT політична стійкість та відсутність насильства / тероризму); Government Effectiveness (GE - ефективність уряду); Regulatory Quality (RQ - якість регулювання); Rule of Law (RL - верховенство права); Control of Corruption (CC - контроль за корупцією). Ці шість комплексних показників базуються на більш ніж 30 джерелах даних. Доступ до бази даних знаходиться за посиланням [6]. Для дослідження використаємо тільки Regulatory Quality (якість регулювання, далі позначатиметься як RQ) та Government Effectiveness (ефективність уряду, GE). 3 метою виявлення залежності між показниками сформовано таблицю кореляції (табл. 1). 
Таблиця 1- Кореляція між показниками Regulatory Quality та Government Effectiveness з іншими показниками Worldwide Governance Indicators

\begin{tabular}{|l|c|c|c|c|c|c|c|}
\hline \multicolumn{1}{|c|}{ Назва показника } & Позн. & RQ & PSAVT & GE & VA & RL & CC \\
\hline Regulatory Quality & RQ & 1,000 & 0,076 & 0,212 & $-0,023$ & 0,369 & 0,531 \\
\hline Government Effectiveness & GE & 0,212 & $-0,576$ & 1,000 & $-0,101$ & 0,273 & 0,433 \\
\hline
\end{tabular}

За аналізом даних 2006-2016 років з дослідження Worldwide Governance Indicators маємо значення кореляції 0,212 між обраними для дослідження показниками (Regulatory Quality, Government Effectiveness). Стосовно інших показників, то «Якість регулювання» (Regulatory Quality) має суттєву кореляцію 3 «контролем за корупцією» (Control of Corruption) - 0,531, найменшу з показником «політична стійкість та відсутність насильства / тероризму» (Political Stability and Absence of Violence/Terrorism) - 0,076.

Стосовно «ефективності уряду» Government Effectiveness, то цей показник також суттєво корелює 3 «контролем за корупцією» (Control of Corruption) - 0,433. Найменша кореляція у цього показника з «верховенством права» (Rule of Law) становить $-0,101$.

3 метою визначення групи країн для дослідження проаналізовано рейтинги, які формувалися за різними методиками, та обрано ті країни, які більшою мірою відповідають ознакам Індустрії-4.0.

У 2016 році лідерами Індустрії-4.0 визнані США (26\%), Німеччина (25\%), Японія (20\%), Франція (8\%), Китай (6\%), Південна Корея (3\%), Нідерланди (3 \%) (у дужках приведено відсоток респондентів за даними [7]). Це експертне дослідження базується на результатах опитування експертів 3 559 промислових підприємств. У них цікавилися думкою про провідну країну в Індустрії-4.0 на 2016 рік.

Показник відношення обсягу високотехнологічного експорту до загального обсягу експорту за даними 2016 року показав такі результати. У TOР-20 країн увійшли Сінгапур, Сан-Томе і Принсіпі, Палау, Філіппіни, Бермуди, Малайзія, Казахстан, Ірландія, Швейцарія, Франція, Південна Корея, Китай, Барбадос, Ісландія, Великобританія, Мальта, США, Норвегія, Киргизія, Ізраїль. Цей показник зовнішньоекономічної діяльності (ЗЕД) для визначених країн становив від 18,38 \% до 67,43\%. Так, викликає подив наявність окремих країн на перших місцях цього рейтингу. Зазначимо, що у 2016 році середній у світі високотехнологічний експорт становив 19,2 \%. У той же час Сан-Томе і Принсіпі, Палау та Бермуди показали значення цього показника від 47,4 \% до $65,5 \%$, що є досить високим значенням. Грунтовний аналіз показав, що саме для цих країн існують певні схеми ввезення, реєстрації та вивезення високотехнологічних товарів через їх митну територію. До того ж для країн Азії цей показник дещо перевищує 25 \%, для країн, що мають значні доходи це менше $20 \%$, для країн Європи всього дещо вище $16 \%$. Україна у 2016 році мала цей показник на рівні 7,2\%. 
Оскільки Індустрія-4.0 базується, насамперед, на інформаційнокомунікаційних технологіях, то доцільно дослідити обсяги експорту та імпорту продукції саме цієї сфери [8]. ТОР-20 за імпортом $є$ такі країни: Сінгапур; Філіппіни; Малайзія; Китай; В'єтнам; Мексика; Чехія; Словаччина; Південна Корея; Тайланд; США; Нідерланди; Японія; Угорщина; Парагвай; Ізраїль; Естонія; Маврикій; Латвія; Швеція. ТОР-20 за експортом є такі країни: Філіппіни; Сінгапур; Малайзія; В'єтнам; Китай; Мальта; Південна Корея; Словаччина; Тайланд; Мексика; Ізраїль; Чехія; Маврикій; Естонія; Антигуа і Барбуда; Угорщина; Латвія; Нідерланди; США; Японія. Одночасно у 2 рейтинги потрапили такі країни: Сінгапур; Філіппіни; Малайзія; Китай; В'єтнам; Мексика; Чехія; Словаччина; Південна Корея; Тайланд; США; Нідерланди; Японія; Ізраїль; Естонія; Латвія.

Порівнюючи перелік за часткою експорту та імпорту IKT, а також за часткою високотехнологічного експорту (тобто перевірили наявність кожної країни одразу у трьох рейтингах), маємо перелік 3 таких семи країн (за алфавітом) Ізраїль, Китай, Малайзія, Південна Корея, Сінгапур, США, Філіппіни.

Експерти до технологічно розвинених країн відносять (з 15 по 1 місце у рейтингу за [9]): Гонконг (Китай); Франція; Японія; Ісландія; Люксембург; Південна Корея; Ірландія; Німеччина; Фінляндія; Сінгапур; Данія; Великобританія; США; Нідерланди; Швеція; Швейцарія. I лише три потрапили у всі вище приведені рейтинги - Китай, Південна Корея, США.

На підставі результатів опрацювання рейтингів основну увагу зосередимо на тих країнах, які потрапили у рейтинг експорту та рейтинг імпорту товарів інформаційно-комунікаційних технологій. До цих країн належать: Сінгапур; Філіппіни; Малайзія; Китай; В'єтнам; Мексика; Чехія; Словаччина; Південна Корея; Тайланд; США; Нідерланди; Японія; Ізраїль; Естонія; Латвія. Для визначення місця України у просторі цих країн, які більшою мірою належать до тих, які мають значну частку у високотехнологічному експорті та імпорті саме продукції ІКТ. Тобто тих країн, що більшою мірою можна віднести до Індустрії-4.0 саме 3 міжнародної точки зору.

На рис. 1 приведено співвідношення експорту та імпорту товарів інформаційно-комунікаційних технологій. Довідково площею круга візуалізовано значення макроекономічного показника ВВП на одну особу. 


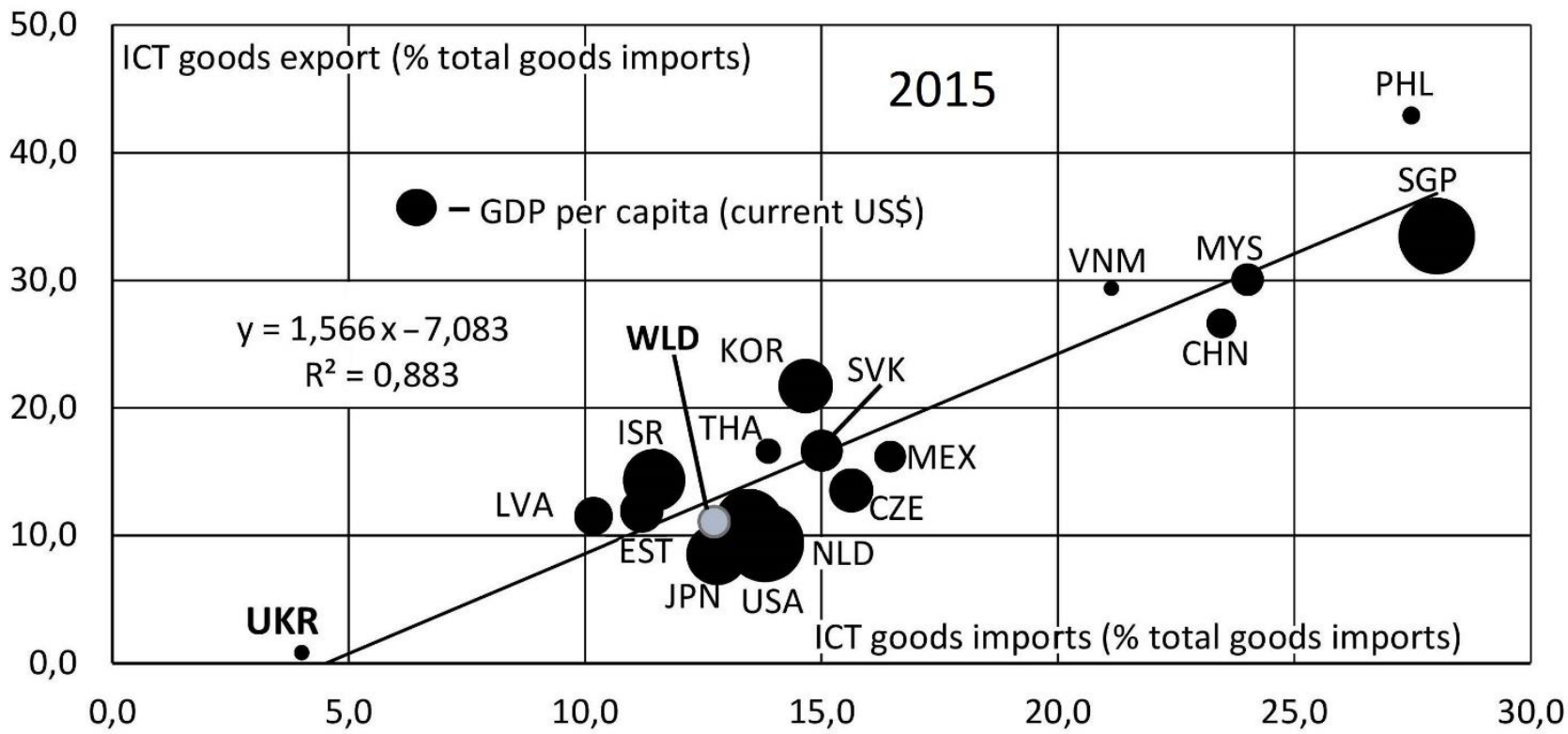

Рисунок 1 - Співвідношення експорту, імпорту товарів інформаційнокомунікаційних технологій та ВВП на одну особу (довідково)

Аналіз співвідношення експорту та імпорту товарів інформаційнокомунікаційних технологій показує, що для країн-лідерів за ЗЕД по ІКТ є суттєвий рівень кореляції між експортом та імпортом, України також відповідає загальносвітовому тренду. Варто відзначити, що «Азійські тигри» - нові індустріальні держави Азії - Сінгапур, Малайзія, Філіппіни, а також Китай та В'єтнам - набагато випереджають основну групу країн Індустрії-4.0 (за експортом / імпортом ІКТ). Ця основна група (центр графіку) знаходиться в околиці точки середньосвітового рівня показників, що досліджуються.

У табл. 2 приведені значення показників, що досліджуються, а також відстань від точки до тренду, відстань від точки до прямої $y=x$, а також відстань по осі регулювання у обраній системі координат показників Regulatory Quality та Government Effectiveness.

Таблиця 2 - Розрахунок відстаней у системі координат Regulatory Quality та Government Effectiveness

\begin{tabular}{|l|c|c|c|c|c|c|}
\hline $\begin{array}{c}\text { Країни } \\
\text { (за алфавітом) }\end{array}$ & $\begin{array}{c}\text { Код } \\
\text { країни }\end{array}$ & $\begin{array}{c}\text { Regulatory } \\
\text { Quality }\end{array}$ & $\begin{array}{c}\text { Government } \\
\text { Effectiveness }\end{array}$ & $\begin{array}{c}\text { Відстань } \\
\text { від } \\
\text { точки до } \\
\text { тренду }\end{array}$ & $\begin{array}{c}\text { Відстань } \\
\text { від } \\
\text { точки до } \\
\text { прямої } \\
\text { у=х }\end{array}$ & $\begin{array}{c}\text { Відстань по } \\
\text { осі } \\
\text { регулювання }\end{array}$ \\
\hline China & CHN & $-0,26$ & 0,36 & 0,428 & 0,442 & 0,62 \\
\hline $\begin{array}{l}\text { Czech } \\
\text { Republic }\end{array}$ & CZE & 0,99 & 1,06 & 0,105 & 0,051 & 0,07 \\
\hline Estonia & EST & 1,70 & 1,12 & 0,319 & 0,413 & 0,58 \\
\hline Israel & ISR & 1,31 & 1,35 & 0,101 & 0,028 & 0,04 \\
\hline Japan & JPN & 1,43 & 1,83 & 0,366 & 0,287 & 0,40 \\
\hline Korea, Rep. & KOR & 1,11 & 1,07 & 0,030 & 0,031 & 0,04 \\
\hline
\end{tabular}




\begin{tabular}{|l|c|c|c|c|c|c|}
\hline Latvia & LVA & 1,08 & 1,00 & 0,001 & 0,059 & 0,08 \\
\hline Malaysia & MYS & 0,71 & 0,88 & 0,160 & 0,121 & 0,17 \\
\hline Mexico & MEX & 0,29 & 0,14 & 0,085 & 0,101 & 0,14 \\
\hline Netherlands & NLD & 1,98 & 1,84 & 0,014 & 0,096 & 0,14 \\
\hline Philippines & PHL & 0,00 & $-0,01$ & 0,006 & 0,006 & 0,01 \\
\hline Singapore & SGP & 2,18 & 2,21 & 0,141 & 0,020 & 0,03 \\
\hline $\begin{array}{l}\text { Slovak } \\
\text { Republic }\end{array}$ & SVK & 0,89 & 0,89 & 0,050 & 0,001 & 0,00 \\
\hline Thailand & THA & 0,17 & 0,34 & 0,128 & 0,119 & 0,17 \\
\hline Ukraine & UKR & $-0,43$ & $-0,58$ & 0,133 & 0,109 & 0,15 \\
\hline United States & USA & 1,50 & 1,48 & 0,071 & 0,011 & 0,02 \\
\hline Vietnam & VNM & $-0,45$ & 0,01 & 0,304 & 0,330 & 0,46 \\
\hline
\end{tabular}

3 метою визначення можливих чинників, які більшою мірою сприяють переходу від класичної виробничо-технологічної системи (Індустрії-3.0) до новітньої (Індустрії-4.0), для окремої країни доцільно проаналізувати показники, які характеризують державну політику. У нашому випадку взято Regulatory Quality (характеризує якість державного регулювання) та Government Effectiveness (показує ефективність діяльності уряду). На рис. 2 приведено візуалізацію співвідношень цих показників. Довідково додано місце у рейтингу за дослідженням Doing Business [10].

На основі аналізу місць розміщення країн у зазначених координатах стверджуємо, що країни, які за ЗЕД по ІКТ відносимо до Індустрії-4.0, мають показник Ефективність уряду вище нуля. Україні ще слід покращувати свої позиції за цим показником з метою потрапляння до когорти країн Індустрії4.0.

За значенням показника Якість регулювання Україна, В'єтнам та Китай мають значення нижче нуля. Зробити висновок за таким станом $є$ досить проблематично, адже це досить різні країни за побудовою державної влади. Проте стосовно нашого дослідження можна стверджувати про ці країни одне для України $є$ шанс належати до країн Індустрії-4.0 із таким рівнем якості регулювання. Не спостерігається певної залежності у розміщенні країн за рейтингом Doing Business та Індустрії-4.0.

На основі табл. 2 сформовано табл. 3 , де прорейтинговано країни за результатами розрахунку відстаней та показників Regulatory Quality та Government Effectiveness. 


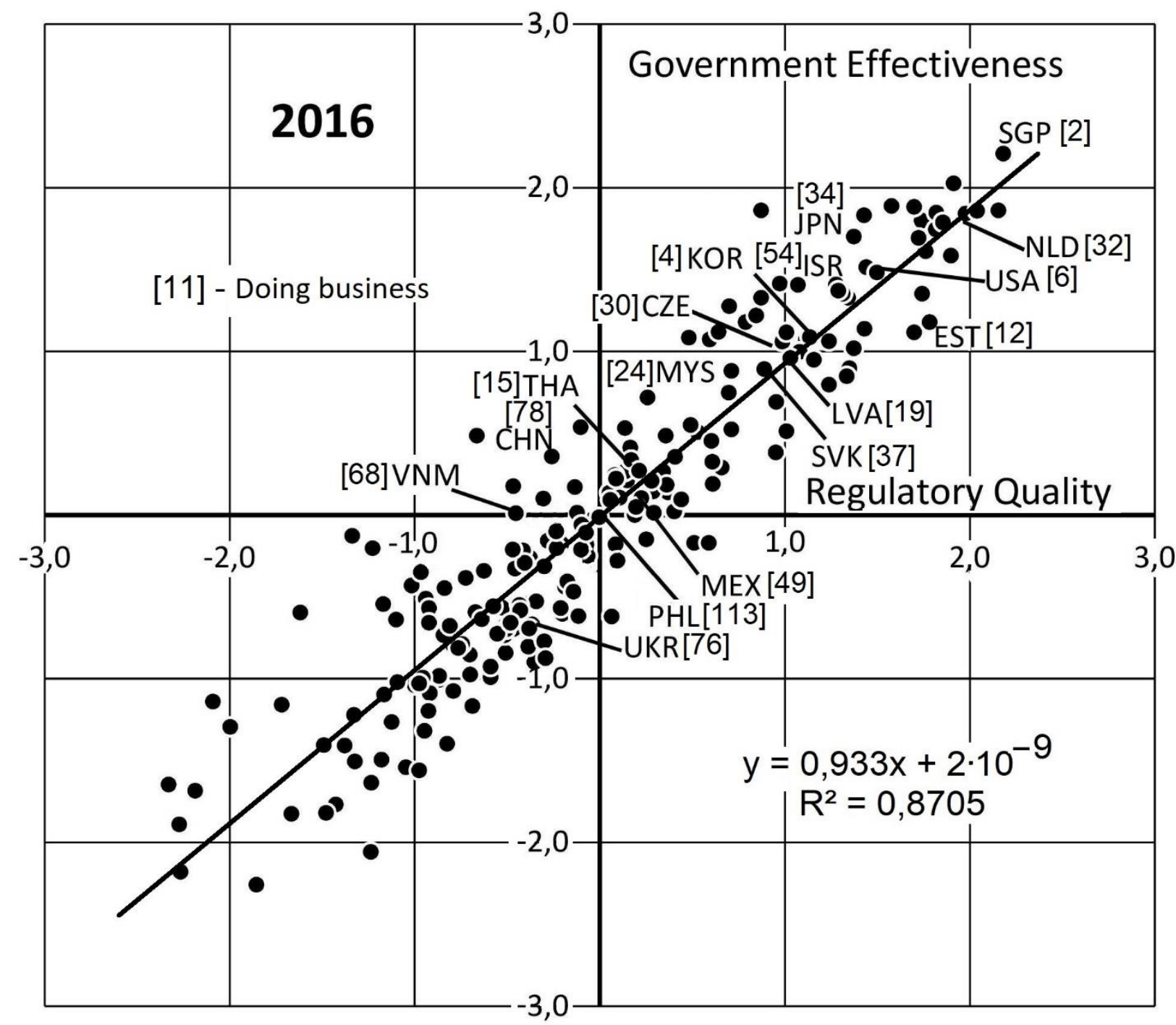

Рисунок 2 - Візуалізація співвідношення показників Якість регулювання та Ефективність уряду (довідково додано рейтинг за індексом Doing Business)

Таблиця 3 - Рейтингування країн за відстанями у системі координат Regulatory Quality та Government Effectiveness

\begin{tabular}{|c|c|c|c|c|c|}
\hline Рейтинг & $\begin{array}{c}\text { Regulatory } \\
\text { Quality }\end{array}$ & $\begin{array}{c}\text { Government } \\
\text { Effectiveness }\end{array}$ & $\begin{array}{c}\text { Відстань } \\
\text { від точки } \\
\text { до тренду }\end{array}$ & $\begin{array}{c}\text { Відстань від } \\
\text { точки до } \\
\text { прямої у=х }\end{array}$ & $\begin{array}{c}\text { Відстань по } \\
\text { осі } \\
\text { регулювання }\end{array}$ \\
\hline 1 & SGP & SGP & LVA & SVK & SVK \\
\hline 2 & NLD & NLD & PHL & PHL & PHL \\
\hline 3 & EST & JPN & NLD & USA & USA \\
\hline 4 & USA & USA & KOR & SGP & SGP \\
\hline 5 & JPN & ISR & SVK & ISR & ISR \\
\hline 6 & ISR & EST & USA & KOR & KOR \\
\hline 7 & KOR & KOR & MEX & CZE & CZE \\
\hline 8 & LVA & CZE & ISR & LVA & LVA \\
\hline 9 & CZE & LVA & CZE & NLD & NLD \\
\hline
\end{tabular}




\begin{tabular}{|c|c|c|c|c|c|}
\hline 10 & SVK & SVK & THA & MEX & MEX \\
\hline 11 & MYS & MYS & UKR & UKR & UKR \\
\hline 12 & MEX & CHN & SGP & THA & THA \\
\hline 13 & THA & THA & MYS & MYS & MYS \\
\hline 14 & PHL & MEX & VNM & JPN & JPN \\
\hline 15 & CHN & VNM & EST & VNM & VNM \\
\hline 16 & UKR & PHL & JPN & EST & EST \\
\hline 17 & VNM & UKR & CHN & CHN & CHN \\
\hline
\end{tabular}

Слід звернути увагу, що відстань від точки до прямої $y=x$ та відстань по осі регулювання до $y=x$ практично не впливає на розміщення країн у рейтингу. Зазначене показує те, що досить важливим є саме якість державного регулювання у набутті країною статусу країни Індустрії-4.0.

Слід відзначити, що Китай має найбільшу (найнижче місце у рейтингу) відстань від точки до тренду, відстань від точки до прямої $y=x$, відстань по осі регулювання. I це при тому, що значення показників Якість регулювання та Ефективність уряду у країні досить низькі. Україна за відстанями посідає 11 позицію у рейтингу при дуже низьких значеннях показників Якість регулювання та Ефективність уряду.

Найкращі позиції за показниками Якість регулювання та Ефективність уряду має Сінгапур, проте відстань до тренду на четвертій позиції. Слід відзначити, що Латвія, Філіппіни, Нідерланди, Південна Корея та Словаччина є близькими до світового тренду. Проте така країна як США посідає лише шосту позицію. Таке місце у рейтингу пояснюється тим, що значна частина високотехнологічних виробництв розміщується поза територією США.

Кращими за рівнем державного регулювання є Сінгапур, Нідерланди, Естонія, США та Японія. А кращими за ефективністю уряду є Сінгапур, Нідерланди, США, Японія та Ізраїль. Україна за цими рейтингами знаходиться у кінці.

Аналіз особливостей розвитку зазначених країн на більш ніж півстолітньому періоді надає змогу стверджувати про те, що більшість 3 них розпочали розвиток завдяки так званому «плану Маршалла» в його різних видах та часових періодах. Так, з першого «плану Маршалла ( 1947 року)» така країни Свропи як Нідерланди вже долучилася до Індустрії-4.0. Пізніше суттєвий розвиток отримали «Азійські тигри»: Сінгапур, Малайзія, Філіппіни, а також Китай (після перегляду своєї економічної політики та формування ринкових відносин) і В'єтнам (після проголошення «політики оновлення» («дой мій») з 1986 року). Подібно до В’єтнаму Південна Корея та Японія прийняла орієнтацію на Захід і стали розвинутими країнами. Колишні країни Радянського Союзу та Соціалістичного табору (Естонія, Латвія, Чехія, Словаччина) також стали прозахідними та стали об'єктами нашого дослідження. На основі цього можна зробити висновок, що й Україна на 
сьогодні обрала вірний вектор і за підтримки, яка подібна до «плану Маршалла», може отримати достойне місце серед країн Індустрії-4.0.

Висновки. На підставі аналізу показників (якість регулювання, ефективність уряду, частка високотехнологічного експорту / імпорту, частка експорту / імпорту інформаційно-комунікаційних технологій), які характеризують належність країни до Індустрії-4.0, визначено можливість і підстави потрапляння України до когорти країн Індустрії-4.0. Кореляційний аналіз підтвердив низький рівень взаємного впливу показників Regulatory Quality (якість регулювання) та Government Effectiveness (ефективність уряду). Не спостерігається значного взаємозв'язку показника Doing Business і групи Regulatory Quality та Government Effectiveness. Визначальними є обсяги імпорту та експорту продукції інформаційно-комунікаційних технологій.

Науковою новизною $\epsilon$ запропонований методичний підхід до визначення можливості та підстав потрапляння країни за класифікаційними ознаками до Індустрії-4.0, який, на відміну від експертних оцінок, використовує статистичні дані та комплексні показники з метою об'єктивного оцінювання стану об'єкту та вироблення відповідних заходів для окремо взятої країни для потрапляння до когорти країн Індустрії-4.0.

Подальших наукових досліджень потребує аналізування динаміки показників з метою визначення оптимального співвідношення їх значень для відповідності показникам країни Індустрії-4.0.

\section{Література:}

1. Schwab, K. The Fourth Industrial Revolution: what it means, how to respond, retrieved from https://www.foreignaffairs.com/articles/2015-12-12/fourth-industrial-revolution

2. Hermann, M., Pentek, T., Otto, B. Design Principles for Industrie 4.0 Scenarios: A Literature Review. Working Paper. Technische Universität Dortmund. 2015. No. 01.16 p.

3. Ostrom, E. Governing the Commons: The Evolution of Institutions for Collective Action. Cambridge. 1990. 280 p.

4. Williamson O. E. Corporate Control and business behavior: an inquiry into the effects of organization form on enterprise behavior. Prentice Hall. 1970. 196 p.

5. Kaufmann, D., Kraay, A., Mastruzzi, M. The Worldwide Governance Indicators: Methodology and Analytical Issues. World Bank Policy Research Working Paper. No. 5430. 31 p.

6. The Worldwide Governance Indicators (WGI) project (2018), retrieved from www.govindicators.org

7. The Statistics Portal (2018), Currently leading in Industry 4.0, retrieved from https://www.statista.com/statistics/667634

8. The World Bank Data and Research (2016), World Bank Statistics Database, retrieved from http://data.worldbank.org

9. Business Insider (2018), The 16 most innovative countries in the world, retrieved from http://www.businessinsider.com/most-innovative-countries-in-the-world-2017-6

10. The Doing Business project (2018, World Bank Group) retrieved from http://www.doingbusiness.org/ 